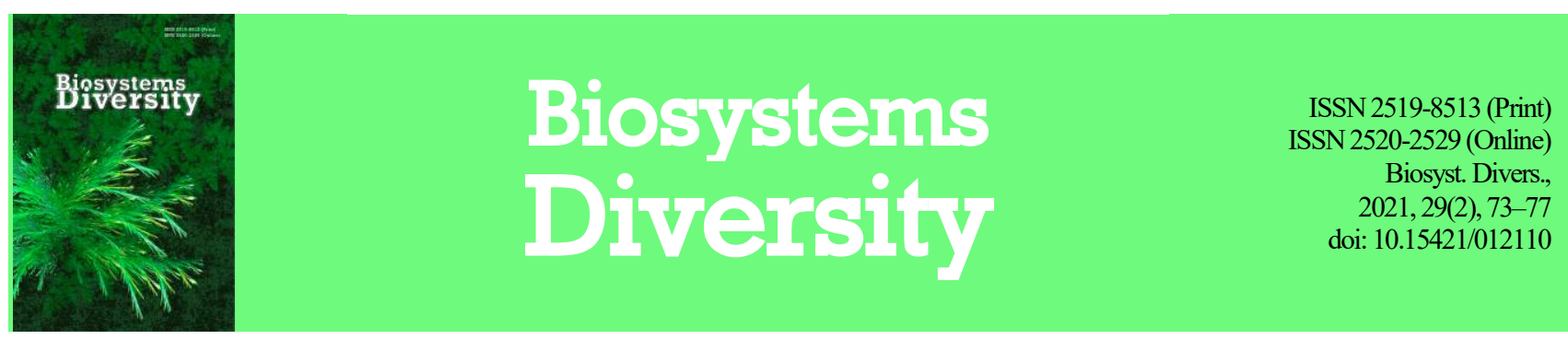

\title{
Antibacterial effect of essential oils of two plants Eucalyptus camaldulensis and Artemisia herba alba on some bacterial strains
}

\author{
H. Fenghour*, H. Bouabida*, D. Dris*, M. Houhamdi** \\ *Larbi Tebessi University, Tebessa, Algeria. \\ **8 May 1945 University, Guelma, Algeria
}

\section{Article info \\ Received 18.03.2021 Received in revised form 12.04 .2021 Accepted 15.04.2021 \\ Larbi Tebessi University, Constantine Road, Tebessa, 12002, Algeria Tel.: +213-662-423-228. E-mail: havette.bouabida @univ-tebessa.dz \\ 8 May 1945 University, Guelma, Algeria Tel.: +213-066-197-28-78 E-mail: h.fenghour @univ-tebessa.dz}

\author{
Fenghour, H., Bouabida, H., Dris, D., \& Houhamdi, M. (2021). Antibacterial effect of essential oils of two plants Eucalyptus camal- \\ dulensis and Artemisia herba alba on some bacterial strains. Biosystems Diversity, 29(2), 73-77. doi:10.15421/012110
}

Essential oils are secondary plant metabolites and have many therapeutic properties. The aim of our study is to determine the antibacterial effect of the essential oils of two plants cultivated in a semi-arid region located in the Northeast of Algeria (Tebessa), Eucalyptus camaldulensis (Myrtaceae) and Artemisia herba alba (Asteraceae). The yield of essential oils of the two plants were $1.45 \pm 0.026$ and $1.21 \pm 0.061 \mathrm{~g} / 100 \mathrm{~g}$ of the dry matter of the aerial part respectively. The test of the antibacterial effect is based on the diffusion method on solid medium (sensitivity), this method allows us to determine the susceptibility or resistance of an organism vis-à-vis the sample studied. Our study reveals that $E$. camaldulensis essential oil had very strong activity on all bacterial strains tested, except on Pseudomonas aeruginosa and Enterococcus faecalis for which there was no inhibitory effect. However, A. herba alba essential oil had very strong activity on all bacterial strains tested except on Pseudomonas aeruginosa. The MIC of Artemisia essential oil ranged between 0.08 and $1.57 \mu \mathrm{L} / \mathrm{mL}$, with the lowest activity for $S$. aureus and $P$. mirabilis $(1.57 \mu \mathrm{L} / \mathrm{mL})$ and the highest activity was observed against E. feacalis, E. coli, and $K$. pneumonia $(0.09 \mu \mathrm{L} / \mathrm{mL})$. The MIC of the second plant EO ranged between 0.08 and $0.36 \mu \mathrm{L} / \mathrm{mL}$, with the lowest activity for P. mirabilis $(0.36 \mu \mathrm{L} / \mathrm{mL})$ and the highest one was observed against $S$. saprophyticus and E. coli $(0.08 \mu \mathrm{L} / \mathrm{mL})$. Statistical analysis shows that the two plants have the same efficacy against $S$. saprophyticus while E. faecalis, $K$. pneumoniae and $P$. mirabilis species are affected more by the essential oil of $A$. herba alba. While, E. camaldulensis has a higher efficiency than that of $A$. herba alba on the species: $S$. aureus and E. coli. Therefore, the essential oils of E. camaldulensis and $A$. herba alba suggests avenues for further non clinical and clinical studies.

Keywords: yield; antibacterial activity; inhibitory effect; secondary metabolites; sensitivity; aromatogram test.

\section{Introduction}

For thousands of years, humankind has used various plants found in its environment, to treat and cure all kinds of diseases (Ghulam et al., 2017). These plants represent an immense reservoir of potential compounds which have the advantage of being of a great diversity of chemical structures and they possess a very wide range of biological activity (Zazharskyi et al., 2019a, 2019b, 2020; Álvarez-Martínez et al., 2020). However, the evaluation of these activities remains a very interesting task which may be of interest to many researchers (Mazari et al., 2010). Medicinal plants are a numerically large group of economically important plants (Pérez-Nicolas et al., 2017). They offer an alternative to drugs and contain active components derived from the secondary metabolites produced from the metabolism of nutrients that are used by human beings in their therapeutic arsenal (Tesche \& Metternich, 2008; Al-Jumaili et al., 2018). These active components are distinguished by several categories such as alkaloids, flavonoids, tannins, essential oils, and other compounds (Mehani, 2015). Essential oils are valuable molecules, used in pharmacology because they have a specific effect on other organisms (Tohidi et al., 2019). In cosmetology (Chaudhuri et al., 2020), they are used as a base for the manufacture of perfume and dermatological products (Kumar et al., 2020). In the food industry they are used to enhance the taste, flavour and colour of food and its conservation. Essential oils have a very broad spectrum of activity due mainly to their great affinity due to their nature, for this, the antibacterial activities of these products have been reported in a large number of studies (Nedjai, 2017). The use of essential oils in medicine has never been abandoned despite the discovery of organic synthesis processes and the birth of the pharmaceutical industry (Baptista-Silva et al., 2020). They are considered as a real reservoir of basic molecules that are irreplaceable (Ouraïni et al., 2007). Considerable interest has been generated in essential oils extracted from aromatic plants and endowed with antimicrobial activity against pathogenic microorganisms (Alzoreky \& Nakahara, 2003; Traore et al., 2013).

Algeria, by its geographical location, offers a rich and diverse vegetation. A large number of aromatic and medicinal plants grow there spontaneously (Bouvet, 2013).

Major in vitro studies proved the antibacterial effect of the plants used in traditional medicine: Satureja hortesis (Gulluce et al., 2003), Albies alba (Bagci \& Digrak, 2003; Yang et al., 2008), Aloe barbadensis (Habeeb et al., 2007), Lavandula angustifolia (Adam et al., 1998; Rota et al., 2004), Hypericum perforatum (Rabanal et al., 2002), Calendula officinalis (Dias Barzon et al., 2008), Mentha piperita (Silva et al., 1994; Tassou et al., 2000), Eucalyptus globulus (Chao et al., 2008), Cocos nucifera (Esquenazi et al., 2002), Eucalyptus essential oil (Kumar, 1988; Chao et al., 2000; Cermelli et al., 2008) and Artemisia (Juteau et al., 2002; Younessi-Hamzekhanlu et al., 2020).

In this study we extracted the essential oil from the leaves of two plants Eucalyptus camaldulensis and Artemisia herba alba asso and quantified the yield. In a second series of experiments, we investigated under laboratory conditions the efficacy of essential oils of the two plants against the selected Gram-positive and Gram-negative bacteria Entrococcus faecalis, Staphylococcus saprophyticus, S. aureus, Escherichia coli, Klebsiella pneumoniae, Pseudomonas aeruginosa, Proteus mirabilis, by the aromatogram test (agar diffusion method) and determination of minimal inhibitory concentration (MIC). The organisms like Escherichia, Klebsiella, Pseudomonas and Staphylococcus species are known to cause severe infections in humans, as they are found in multiple environmental habitats (Trombetta et al., 2005). The aim was to indicate the potential usefulness of the two plants $E$. camaldulensis and $A$. herba alba as a microbiostatic, antiseptic or as a disinfectant agent. In addition, a statistical analysis was 
carried out to determine the significant effect of the essential oils of the two plants on the set of bacteria tested.

\section{Materials and methods}

The leaves of $E$. camaldulensis and A. herba alba were collected in the month of January 2020 in Tebessa (Northeast Algeria) in the following coordinates: $35^{\circ} 20^{\prime} 46^{\prime \prime} \mathrm{N}, 8^{\circ} 15^{\prime} 18^{\prime \prime} \mathrm{E}$ and $1040 \mathrm{~m}$ above sea level for E. camaldulensis and $35^{\circ} 29^{\prime} 39^{\prime \prime} \mathrm{N}, 8^{\circ} 20^{\prime} 12^{\prime \prime} \mathrm{E}$ and $1028 \mathrm{~m}$ sea level. The harvesting was carried out in the afternoon, and was taken only from the aerial part of the adult tree; chosen at random. The samples were dried well at room temperature and protected from light and moisture for a period of 10 days and were stored in clean bags to remove any impurities.

The essential oil of E. camaldulensis and $A$. herba alba was extracted from dried leaves, submitted to hydrodistillation in Clevenger apparatus. After collection, samples of $100 \mathrm{~g}$ were subjected to hydrodistillation for $3 \mathrm{~h}$ with $1 \mathrm{~L}$ distilled water. The essential oil was collected and water droplets were removed using sodium sulfate and stored in amber and refrigerated bottles. The yield of essential oil is the ratio between the weight of the oil extracted and the weight of the dry matter of the plant (Bouabida \& Dris, 2020).

Bacterial strains of Enterococcus faecalis, Staphylococcus aureus, Pseudomonas aeruginosa, Escherichia coli, Klebsiella pneumonia and Proteus mirabilis (Table 1) were provided by the microbilogical laboratory of clinic of Tebessa. The identification of strains was confirmed by the use of biochemical profiles according to the recommendation of the Manual of Clinical Microbiology (Murray, 2003).

Table 1

Characteristics of the bacterial strains tested

\begin{tabular}{lll}
\hline Family & Bacterial strains & Bacterial strains \\
\hline Enterococcaceae & Enterococcus faecalis & ATCC 29212 \\
\hline \multirow{2}{*}{ Enterobacteriaceae } & Klebsiella pneumoniae & ATCC 10031 \\
& Escherichia coli & ATCC 11303 \\
& Proteus mirabilis & ATCC 25933 \\
\hline \multirow{2}{*}{ Staphylococcaceae } & Staphylococcus saprophyticus & ATCC 15305 \\
& Staphylococcus aureus & ATCC 25923 \\
\hline Pseudomonadaceae & Pseudomenas aeruginosa & ATCC 9027 \\
\hline
\end{tabular}

Aromatogram test (agar diffusion method) is an in vitro method of measuring the antibacterial power of essential oils. To seed $1 \mathrm{~mL}$ of the bacterial inoculum in the petri dishes previously melted with MuellerHinton agar a suspension of each of the bacterial isolates, to be used in the tests, was adjusted to a turbidity matching that of a $0.5 \mathrm{McFarland}$ standard, equivalent to $1.5 \times 10^{8} \mathrm{CFU} / \mathrm{mL}$ (Donay, 2007; Balouiri, 2016). Six disks of blotting paper ( $0.6 \mathrm{~cm}$ diameter) aseptically impregnated with 10 , $5,2.5,1.25$ and $0.62 \mu \mathrm{L}$ of essential oils were deposited on the agar surface (De Billerbeck, 2002; Pibiri, 2005). All tests were repeated 4 times. After a latency period at $37^{\circ} \mathrm{C}$ for $16-18 \mathrm{~h}$, the inhibition zone surrounding the disks was measured (Boland et al., 1991; Euzéby, 1998; Franchomme, 1999; Farah et al., 2001; Cimanga et al., 2002). The sensitivity of bacterial strains depending on the inhibition zones was interpreted according to Table 2 .

Table 2

Sensitivity of bacterial strains depending

on the inhibition zones (Ponce et al., 2003)

\begin{tabular}{lc}
\hline \multicolumn{1}{c}{ Sensitivity } & Diameter of inhibition zone, $\mathrm{mm}$ \\
\hline No sensitive or resistant $(-)$ & $<8$ \\
Sensitive $(+)$ & $9-14$ \\
Very sensitive $(++)$ & $15-19$ \\
Extremely sensitive $(+++)$ & $>20$ \\
\hline
\end{tabular}

The micro-dilution broth method was used to determine the Minimal Inhibitory Concentration (MIC) according to Yu et al. (2004). The essential oil diluted in DMSO was mixed with a $100 \mathrm{~mL}$ Mueller-Hinton. Serial dilutions of the oil were prepared in a 96-well microtiter plate ranged from 0.08 to $25 \mu \mathrm{L} / \mathrm{mL}$. Finally, an inoculum containing $1.5 \times 10^{8}$ CFU $(10 \mu \mathrm{L})$ per well was added to the broth with various oil concentrations. Two columns in each plate were used as controls: one column with a broad-spectrum antibiotic as a positive control (amykacine), and one column containing DMSO as a negative control. The control media containing only DMSO did not inhibit the growth of bacterial strains. The plates were prepared in quadruple, and then they were placed in an incubator at $37{ }^{\circ} \mathrm{C}$ for $18-24$ hours under aerobic conditions. After incubation time, the growth of cultures were checked visually. The MIC is defined as the lowest concentration of the essential oil at which the microorganism does not demonstrate the visible growth. The microorganism growth was indicated by turbidity (Harauma et al., 2007).

The level of significance for the analyses was set at $\mathrm{P}<0.05$. To compare the effectiveness of the two plants on the different bacterial strains, the two way ANOVA followed by multiple comparison of means (Tukey's test) was performed on the lysis diameters of the highest concentration $10 \mu \mathrm{L}$. Statistical analyses of the means \pm standard deviation were performed using the software program GraphPad Prism 8 (www.graphpad.com).

\section{Results}

The yield of essential oil extracted from the dry matter of the aerial part of E. camaldulensis and A. herba alba of two plants was $1.45 \pm 0.026$ and $1.21 \pm 0.061 \mathrm{~g}$ respectively. The following table shows the results of tests of antibacterial activity of essential oils from the plants E. camaldulensis and A. herba alba on bacterial strains. The antibacterial activity of essential oil is determined by measuring the diameter of the zone of inhibition formed around each disc, the sensitivity of bacteria to essential oil has been classified according to the diameter of the inhibition halos as summarized in Table 3.

Table 3

Zone of inhibition of bacterial strains against essential oil $(\mu \mathrm{L})$ of Eucalyptus camaldulensis $(\mathrm{x} \pm \mathrm{SD}, \mathrm{n}=4)$

\begin{tabular}{lccccc}
\hline \multirow{2}{*}{ Bacterial strains } & \multicolumn{5}{c}{ Zone of inhibition, mm } \\
\cline { 2 - 6 } & $10 \mu \mathrm{L}$ & $5 \mu \mathrm{L}$ & $2.5 \mu \mathrm{L}$ & $1.25 \mu \mathrm{L}$ & $0.62 \mu \mathrm{L}$ \\
\hline E. faecalis & 0 & 0 & 0 & 0 & 0 \\
S. saprophyticus & $12.03 \pm 0.15$ & 0 & 0 & 0 & 0 \\
S. aureus & $17.50 \pm 0.50$ & 0 & 0 & 0 & 0 \\
E. coli & $15.60 \pm 0.53$ & $9.23 \pm 0.15$ & $8.32 \pm 0.12$ & 0 & 0 \\
K. pneumonia & $13.66 \pm 1.52$ & $8.23 \pm 0.25$ & $7.31 \pm 0.10$ & $6.09 \pm 0.10$ & $5.43 \pm 0.42$ \\
P. aeruginosa & 0 & 0 & 0 & 0 & 0 \\
P. mirabilis & $8.20 \pm 0.21$ & 0 & 0 & 0 & 0 \\
\hline
\end{tabular}

Table 4

Zone of inhibition of bacterial strains against essential oil $(\mu \mathrm{L})$ of Artemisia herba alba $(\mathrm{x} \pm \mathrm{SD}, \mathrm{n}=4)$

\begin{tabular}{lccccc}
\hline \multirow{2}{*}{$\begin{array}{c}\text { Bacterial } \\
\text { strains }\end{array}$} & $10 \mu \mathrm{L}$ & $5 \mu \mathrm{L}$ & $2.5 \mu \mathrm{L}$ & $1.25 \mu \mathrm{L}$ & $0.62 \mu \mathrm{L}$ \\
\cline { 2 - 6 } E. faecalis & $13.36 \pm 1.20$ & $13.01 \pm 0.10$ & $12.00 \pm 0.17$ & $10.03 \pm 0.12$ & $9.33 \pm 0.41$ \\
S. saprophyticus & $12.46 \pm 0.58$ & $12.13 \pm 0.20$ & $11.20 \pm 0.17$ & $10.44 \pm 0.10$ & 0 \\
S. aureus & $10.40 \pm 0.17$ & $9.60 \pm 0.10$ & 0 & 0 & 0 \\
E. coli & $13.03 \pm 0,83$ & $9.60 \pm 0.10$ & $8.59 \pm 0.05$ & $7.77 \pm 0.02$ & $6.61 \pm 0.20$ \\
K. pneumonia & $17.56 \pm 1.36$ & $13.33 \pm 0.98$ & $9.21 \pm 0.10$ & $8.83 \pm 0.10$ & $8.52 \pm 0.10$ \\
P. aeruginosa & 0 & 0 & 0 & 0 & 0 \\
P. mirabilis & $10.10 \pm 0.26$ & $9.26 \pm 0.11$ & $8.02 \pm 0.10$ & 0 & 0 \\
\hline
\end{tabular}

E. camaldulensis and $A$. herba alba essential oil had very strong activity on all bacterial strains tested $8<\mathrm{D}<17 \mathrm{~mm}$ (Table 2), except on $P$. aeruginosa and E. faecalis, which resisted the effect of E. camaldulensis essential oil (Table 3) while only $P$. aeruginosa was resistant to the effect of Artemisia essential oil (Table 4). In fact, we noticed a significant decrease in the percentage of inhibition with the following bacterial strains: $S$. aureus and E. coli, which were very sensitive. E. faecalis, $K$. pneumoniae, S. saprophyticus and $P$. mirabilis were sensitive.

The results of the antibacterial broth micro dilution assay are summarised in Table 5. MIC values did not exhibit substantial variations when compared to the trend of inhibition shown with the agar diffusion method. Generally, larger inhibition zone values correlated with lower MIC. Eucalyptus and Artemisia essential oil showed a high activity against a majority of the selected bacteria. With Artemisia essential oil, MIC ranged between 0.08 and $1.57 \mu \mathrm{L} / \mathrm{mL}$, with the lowest activity for $S$. aureus and $P$. mirabilis $(1.57 \mu \mathrm{L} / \mathrm{mL})$ while the highest activity was observed against $E$. feaca- 
lis, E. coli, and K. pneumonia $(0.09 \mu \mathrm{L} / \mathrm{mL})$.With Eucalyptus essential oil, MIC ranged between 0.08 and $0.36 \mu \mathrm{L} / \mathrm{mL}$, with the lowest activity for P. mirabilis $(0.36 \mu \mathrm{L} / \mathrm{mL})$ while the highest activity was observed against S. saprophyticus, E. coli $(0.08 \mu \mathrm{L} / \mathrm{mL})$ and $S$. aureus, $K$. pneumonia $(0.09 \mu \mathrm{L} / \mathrm{mL})$.

Table 5

Antibacterial activity of Eucalyptus camaldulensis and Artemisia herba alba essential oil expressed as minimum inhibitory concentration (MIC)

\begin{tabular}{lcc}
\hline \multirow{2}{*}{ Bacterial strains } & \multicolumn{2}{c}{ Minimum inhibitory concentration (MIC), $\mu \mathrm{L} / \mathrm{mL}$} \\
\cline { 2 - 3 } & Eucalyptus camaldulensis & Artemisia herba alba \\
\hline E. faecalis & - & 0.08 \\
S. saprophyticus & 0.08 & 0.18 \\
S. aureus & 0.09 & 1.57 \\
E. coli & 0.08 & 0.09 \\
K. pneumonia & 0.09 & 0.09 \\
P. aeruginosa & - & - \\
P. mirabilis & 0.36 & 1.57 \\
\hline
\end{tabular}

The multiple comparison of means show that the two plants have the same efficacy against $S$. saprophyticus $(\mathrm{P}=0.985)$. In contrast, E. faecalis, $K$. pneumoniae and $P$. mirabilis are affected more by the essential oil of A. herba alba $(\mathrm{P}<0.0001 ; \mathrm{P}<0.0001$ and $\mathrm{P}=0.039$, respectively). So the essential oil of $E$. camalulensis has a higher efficiency than that of A. herba alba on the species $S$. aureus $(\mathrm{P}<0.0001)$ and $E$. coli $(\mathrm{P}=0.003)$ (Fig. 1).

\section{Discussion}

The yield of essential oil extracted from the dry matter of the aerial part of E. camaldulensis is $1.45 \pm 0.026 \mathrm{~g}$, our results are similar to those of (Mehani, 2015) who found a yield $0.99 \%$. A study by (Ashraf et al., 2010), on Eucalyptus leaves in Pakistan and Morocco revealed an essential oil content of between $(0.90-0.98 \%)$. Some authors including (Chalchat et al., 2000) estimated a return of $(0.5 \%)$, another study conducted by Bejaia (Makhlouf et al., 2016) found an equivalent yield (3.1\%), a considerably high essential oil yield was reported for Taiwan Eucalyptus (2.33.0\%) (Chalchat et al., 2000).

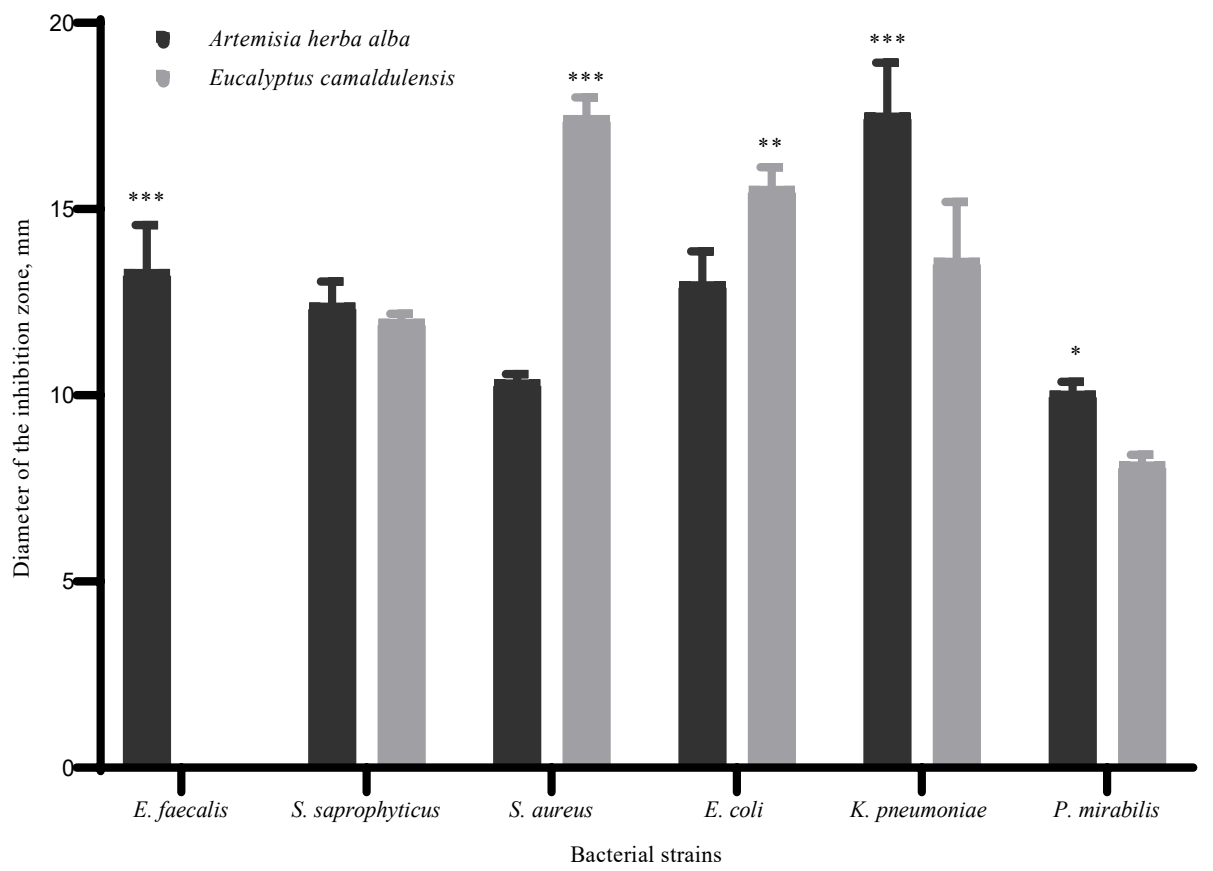

Fig. 1. Comparative efficiency of essential oils extracted from $A$. herba alba and $E$. camaldulensis against bacterial strains $(\mathrm{x} \pm \mathrm{SD}, \mathrm{n}=4$ repetitions):

${ }^{*}$ - difference compared the diameter of the inhibition zone is statistically reliable at $\mathrm{P}<0.05,{ }^{* *}-\mathrm{P}<0.01$, *** $-\mathrm{P}<0.001$

The essential oil isolated by hydrodistillation of the aerial parts of A. herba alba had a yield of $1.21 \pm 0.061 \mathrm{~g}$. This yield is lower compared to $1.3 \%(\mathrm{v} / \mathrm{w})$ from dried tops (Hudaib \& Aburjai, 2006) and $1.02 \%$ on a dry weight basis for $A$. herba alba growing in the wild in M'sila-Algeria (Dob \& Benabdelkader, 2006) and a yield of $0.71 \%$ reported in Tafingoult in Morocco (Asdadi et al., 2020). In general, these differences between the different results are due to different factors: plant species, seasons, geographical regions, products and reagents used in the extraction of essential oils, harvest period, the degree conditions time and the drying temperature and the presence of weeds (Ghasemian, 2019).

The essential oils of $E$. camaldulensis and $A$. herba alba have a broad spectrum of antibacterial activity against Gram + and Gram - bacteria. Similar results have been reported by Daroui-Mokaddem (2012) which shows that the essential oil has a very strong activity against $S$. aureus and E. coli; also Mehani (2015) showed that $P$. aeruginosa has a resistant power and Proteus mirabilis is sensitive to the activity of the essential oil. Indeed, the sensitivity of microorganisms depends on the chemical composition and the concentration of essential oils used and the type of microorganisms tested (Farah et al., 2001). The crude extracts of E. camaldulensis and A. herba alba acted to perceptibly inhibit the growth of selected pathogenic bacteria. An inhibitory activity of essential oils was found against gram-positive bacteria and gram-negative bacteria. Different investigations have examined the efficacy of essential oils against gram positive and negative bacteria, and shown that gram positive bacteria are more susceptible to oils (Smith-Palmer, 1998; Inouye, 2001). In our research, essential oil of E. camaldulensis didn't have any antibacterial activity against $E$. feacalis even at highest concentration. Presence of the polysaccharide capsule in this species of bacteria can act as a barrier to the transmission of active antibacterial compounds. It could also be due to the differences among chemical components of plants that have been cultivated in divergent ecological regions. Tebessa, a town in North East of Algeria, has a very dry and warm climate and the weather condition is very decisive in producing officinal substances (Seyyednejad et al., 2010).

The results also indicated that a higher volume of the essential oil $(10 \mu \mathrm{L})$ was required to inhibit the growth of all Gram positive and Gramnegative bacteria tested. These results are similar to those found by (Farah et al., 2001; Trivedi \& Hotchandani, 2004; Nair et al., 2008). It is worth noting, however, that $P$. aeroginosa isolate was resistant to all the volumes of essential oil used in this study. Since Pseudomonas species are known to have the ability to metabolise a wide range of organic compounds and because of this is used extensively in bioremediation, this may explain their high level of resistance. They may simply metabolise the compounds in the oils that are inhibitory to many of the other bacteria (Chao et al., 2000). This and other variations in the sensitivity of different isolates of even the same species are known to be due to different genetic profiles conferring varying resistance patterns. The genetic plasticity of bacteria 
allows them to overcome the threat of antibiotics so that only the fittest will survive and adapt to newer environments (Munita, 2016). Although the antibacterial activities of the essential oils from many herb species have been extensively surveyed (Rios, 2005), their antimicrobial mechanisms have not been reported in great detail (Shunying et al., 2005). Any individual essential oil contains complex mixtures of such compounds, however, little is known about the effect of the interaction between the individual constituents on the antimicrobial activity. Interactions between the constituents may lead to additive, synergistic, or antagonistic effects (Delaquis et al., 2002).

\section{Conclusion}

The present study confirmed the antibacterial properties of essential oils from E. camaldulensis and A. herba alba, which showed significant growth inhibition for $S$. aureus, S. saprophyticus, E. coli, K. pneumonia and $P$. mirabilis tested, which present a threat due to the emergence of strains that possess multiple resistance to a range of antibiotics, thereby making them difficult to treat. The encouraging results indicate the $E$. camaldulensis and $A$. herba alba might be exploited as natural antibiotics for the treatment of several infectious diseases caused by these five germs, and could be useful in understanding the relations between traditional cures and current medicines.

\section{References}

Adam, K., Sivropoulou, A., Kokkini, S., Lanaras, T., \& Arsenakis, M. (1998). Antifungal activities of Origanum vulgare subsp. hirtum, Mentha spicata, Lavandula angustifolia, and Salvia fruticosa essential oils against human pathogenic fungi. Joumal of Agricultural and Food Chemistry, 46(5), 1739-1745.

Al-Jumaili, A., Kumar, A., Bazaka, K., \& Jacob, M. V. (2018). Plant secondary metabolite-derived polymers: A potential approach to develop antimicrobial films. Polymers, 10(5), 515.

Álvarez-Martínez, F. J., Barrajón-Catalán, E., \& Micol, V. (2020). Tackling antibiotic resistance with compounds of natural origin: A comprehensive review. Biomedicines, 8(10), 405.

Alzoreky, N. S., \& Nakahara, K. (2003). Antimicrobial activity of extracts from some edible plants commonly consumed in Asia. International Joumal of Food Microbiology, 80(3), 223-230.

Asdadi, A., Hamadouch, A., Gharby, S., \& Idrissi Hassani, L. M. (2020). Chemical characterization of essential oil of Artemisia herba-alba Asso and his possible potential against COVID-19. Journal of Analytical Sciences and Applied Biothechnology, 2(2), 67-72.

Ashraf, M., Ali, O., Anwar, F., \& Hussain, A. (2010). Composition of leaf essential oil of Eucalyptus camaldulensis. Asian Joumal of Chemistry, 22(3), 1779 1786.

Bagci, E., \& Digrak, M. (2003). Antimicrobial activity of essential oils of some Abies (Fir) species from Turkey. Flavour and Fragrance Journal, 11(4), 251-256.

Balouiri, M., Sadiki, M., \& Ibnsouda, S. K. (2016). Methods for in vitro evaluating antimicrobial activity: A review. Journal of Pharmaceutical Analysis, 6(2), 71-79.

Baptista-Silva, S., Borges, S., Ramos, O. L., Pintado, M., \& Sarmento, B. (2020). The progress of essential oils as potential therapeutic agents: A review. Joumal of Essential Oil Research, 32(4), 279-295.

Boland, D. J., Brophy, J. J., \& House A. P. N. (1991). Eucalyptus leaf oils: Use, chemistry, distillation and marketing. Inkata Press, Melbourne.

Bouabida, H., \& Dris, D. (2020). Effect of rue (Ruta graveolens) essential oil on mortality, development, biochemical and biomarkers of $C$ uliseta longiareolata. South African Journal of Botany, 133, 139-143.

Bouvet, J. (2013). Les Eucalyptus dans le monde, L'eucalyptus une essence majeure pour le reboisement à Madagascar, Antananarivo-Madagascar, Ankatso. Université d'Antananarivo.

Cermelli, C., Fabio, A., Fabio, G., \& Quaglio, P. (2008). Effect of Eucalyptus oil on respiratory bacteria and viruses. Current Microbiology, 56(1), 89-92.

Chalchat, J. C., Gary, R. P., Sidibe, L., \& Harama, M. (2000). Aromatic plants of Mali (V): Chemical composition of four Eucalyptus species implanted in Mali, Eucalyptus camaldulensis, E. torelliana, E. citriodora, E. tereticornis. Joumal of Essential Oil Research, 12(6), 695-701.

Chao, S. C., Young, D. G., \& Oberg, C. J. (2000). Screening for inhibitory activity of essential oils on selected bacteria, fungi and viruses. Joumal of Essential Oil Research, 12(5), 639-649.

Chao, S. C., Young, D. G., Oberg, C. J., \& Nakaoka, K. (2008). Inhibition of methicillin-resistant Staphylococcus aureus (MRSA) by essential oils. Flavour and Fragrance Journal, 23(6), 444449.
Chaudhuri, A., Aqil, A., \& Qadir, A. (2020). Herbal cosmeceuticals: New opportunities in cosmetology. Trends in Phytochemical ResearchTrend, 4(3), 117-142.

Cimanga, K., Kambu, K., Tona, L., Apers, S., De Bruyne, T., Hermans, N., Totté, J., Pieters, L., \& lietinck, A. J. (2002). Correlation between chemical composition and antibacterial activity of essential oils of some aromatic medicinal plants growing in the Democratic Republic of Congo. Journal of Ethnopharmacology, 79(2), 213-220.

Daroui-Mokaddem, H. (2012). Etude phytochimique et biologique des especes Eucalyptus globulus (Myrtaceae), Smyrnium olusatrum (Apiaceae), Asteriscus maritimus et Chrysanthemum trifurcatum (Asterarceae). Thèse de Doctorat en Biochimie Appliquée. Universite Badji Mokhtar-Annaba.

De Billerbeck, V. G., Roques, C., Vaniere, P., \& Marquier, P. (2002). Activité antibactérienne et antifongique de produits à base d'huiles essentielles. Hygiennes, 3, 248-251.

Delaquis, P. J., Stanich, K., Girard, B., \& Mazza, G. (2002). Antimicrobial activity of individual and mixed fractions of dill, cilanto, coriander and Eucalyptus essential oils. International Joumal of Food Microbiology, 74, 101-109.

Dias Barzon, C., de Medeiros, F., Moraes, R. E., Monteiro da Silva, L. C., Massambani, C., Takemura, O. S., \& Gazim, Z. C. (2008). Preliminary study of homeopathic treatment of subclinical mastitis evaluated through somatic cells count and California mastitis test. International Journal of High Dilution Research, 7(24), 147-151.

Dob, T., \& Benabdelkader, T. (2006). Chemical composition of the essential oil of Artemisia herba-alba Asso grown in Algeria. Joumal of Essential Oil Research, 18(6), 685-690.

Donay, J. L., Fernandes, P., Lagrange, P. H., \& Herrmann, J. L. (2007). Evaluation of the inoculation procedure using a $0.25 \mathrm{McF}$ arland standard for the $\mathrm{BD}$ phoenix automated microbiology system. Journal of Clinical Microbiology, 45(12), $4088-4089$.

Esquenazi, D. M. D., Wigg, M. M., Miranda, H. M., Rodrigues, J. B., Tostes, S., Rozental da Silva, A. J., \& Alviano, C. S. (2002). Antimicrobial and antiviral activities of polyphenolics from Cocos nucifera Linn. (Palmae) husk fiber extract. Research in Microbiology, 153(10), 647-652.

Euzéby, J. P. (1998). Évaluation in vitro de la sensibilité des bactéries aux antibiotiques. Dictionnaire de Bactériologie Vétérinaire.

Farah, A., Satrani, B., Fechtal, M., Chaouch, A., \& Talbi, M. (2001). Composition chimique et activités antibactérienne et antifongique des huilesessentielles extraites des feuilles d' Eucalyptus camaldulensis et de son hybride naturel (clone 583). Acta Botanica Gallica, 148(3), 183-190.

Franchomme, P. (1999). L'aromathérapie thérapeutique de pointe en médecine naturelle. Sinceiro Entreprises Ltd., Hong Kong.

Ghasemian, A., Eslami, M., Hasanvand, F., Bozorgi, H., \& Al-Abodi Hiba, R. (2019). Eucalyptus camaldulensis properties for use in the eradication of infections. Comparative Immunology, Microbiology and Infectious Diseases, 65, 234-237.

Ghulam, M., Rawaba, A., Asia, A., Sumaira, S., \& Amer, J. (2017). Bioactive compounds from medicinal plants and their importance in drug discovery in Pakistan. Matrix Science Pharma, 1(1), 17-26.

Güllücẹ., Sökmen M., DafererąD., Ağar G., Özkan H., KartallN., Polissioł M., SokemenA., \&ŞahiņF. (2003). In vitro antibacterial, antifungal, and antioxidant activities of the essential oil and methanol extracts of herbal parts and callus cultures of Satureja hortensis L. Journal of Agricultural and Food Chemistry, 51(14), 3958-3965.

Habeeb, F., Shakir, F., Bradbury, F., Cameron, P., Taravati, M. R., Drummond, A. J., Gray, A. I., \& Ferro, V. A. (2007). Screening methods used to determine the antimicrobial properties of Aloe vera inner gel. Methods, 42(4), 315-320.

Harauma, A., Murayama, T., Ikeyama, K., Sano, H., Arai, H., Takano, R., Kita, T., Hara, S., Kamei, K., \& Yokode, M. (2007). Mulberry leaf powder prevents atherosclerosis in apolipoprotein E-deficient mice. Biochemical and Biophysical Research Communications, 358(3), 751-756.

Hudaib, M. M., \& Aburjai, T. A. (2006). Composition of the essential oil from Artemisia herba-alba grown in Jordan. Journal of Essential Oil Research, 18(3), 301-304.

Inouye, S., Takizawa, T., \& Yamaguchi, H. (2001). Antibacterial activity of essential oils and their major constituents against respiratory tract pathogens by gaseous contact. Journal of Antimicrobial Chemotherapy, 47(5), 565-573.

Juteau, F., Msotti, V., Bessiene, J. M., \& Viano, J. (2002). Compositional charateristics of essential oils of Artemisia vulgris L. (Mugwort) from North Lithuani. Biochemical Systematics and Ecology, 17, 12-15.

Kumar, A. (1988). Antibacterial properties of some Eucalyptus oils. Fitoterapia, 59, $113-123$.

Kumar, M., Devi, A., Sharma, M., Kaur, P., \& Mandal, U. K. (2020). Review on perfume and present status of its associated allergens. Journal of Cosmetic Dermatology, 30, 1065-1070.

Makhlouf, L., Bey, Z., \& Khodir, M. (2016). Essential oils composition, antibacterial and antioxidant activities of hydrodistillated extract of Eucalyptus globulus fruits. Journal of Microbial and Biochemical Technology, 89, 167-175. 
Mazari, K., Bendinerad, N., \& Benkhechi, C. (2010). Chemical composition and antimicrobial activity of essential oil isolated from Algerian Juniperus phoenicea L. and Cupressus sempervirens L. Médicinal Plant Research, 4(10), 959-964.

Mehani, M. (2015). Activité antimicrobienne des huiles essentielles d'Eucalyptus camaldulensis dans la région d'Ouargla. Thèse de doctorat, Microbiologie. Ouargla. Faculté des Sciences de la Nature et de la Vie, Département des Sciences Biologiques.

Munita, J. M., \& Arias, C. A. (2016). Mechanisms of antibiotic resistance. In: Kudva, I. T., Cornick, N. A., Plummer, P. J., Zhang, Q., Nicholson, T. L., Bannantine, J. P., \& Bellaire, B. H. (Eds.). Virulence mechanisms of bacterial pathogens. 5th edition. American Society for Microbiology. Pp. 481-511.

Murray, P. R., Baron, E. J., Jorgenson, J. H., Pfaller, M. A., \& Yolken, R. H. (2003). Manual of clinical microbiology. 8th edition. American Society for Microbiology Press, Washington.

Nair, R., Vaghasiya, Y., \& Chanda, S. (2008). Antibacterial activity of Eucalpytus citriodora $\mathrm{Hk}$. oil on few clinically important bacteria. African Journal of Biotechnology, 7, 25-26.

Nedjai, S. (2017). Activité antimicrobienne des huiles essentielles. Mémoire de mater: Ecologie microbienne. Université A. MIRA Bejaia, Bejaia.

Ouraïni, D., Agoumi, A., Ismaili-Alaoui, M., Alaoui, K., Cherrah, Y., Alaoui, M. A., \& Belabbas, M. A. (2007). Activité antifongique de l'acide oléique et des huiles essentielles de Thymus saturejoides L. et de Mentha pulegium L., comparée aux antifongiques dans les dermatoses mycosiques. Phytothérapie, 5(1), 6-14.

Pérez-Nicolas, M., Vibrans, H., Romero-Manzanares, A., Saynes-Vasquez, A., Luna-Cavazosa, M., Flores-Cruz, M., \& Lira-Saade, R. (2017). Patterns of knowledge and use of medicinal plants in Santiago Camotlán, Oaxaca, Mexico. Economic Botany, 71(3), 209-223.

Pibiri, M. C. (2005). Assainissement microbiologique de l'air et des systèmes de ventilation au moyen dhuiles essentielles. Thèse de doctorat des sciences. École Polytechnique Fédérale de Lausanne.

Ponce, A. G., Fritz, R., del Valle, C., \& Roura, S. I. (2003). Antimicrobial activity of essential oils on the native microflora of organic Swiss chard. LWT - Food Science and Technology, 36(7), 679-684.

Rabanal, R. M., Arias, A., Prado, B., Hernández-Pérez, M., \& Sánchez-Mateo, C. C. (2002). Antimicrobial studies on three species of Hypericum from the Canary Islands. Journal of Ethnopharmacology, 81, 287-292.

Rios, J. L., \& Recio, M. C. (2005). Medicinal plants and antimicrobial activity. Journal of Ethnopharmacology, 100, 80-84.

Rota, C., Carramiñan, J. J., Burillo, J., \& Herrera, A. (2004). In vitro antimicrobial activity of essential oils from aromatic plants against selected foodborne. Pathogens Joumal of Food Protection, 67(6), 1252-1256.

Seyyednejad, S. M., Koochak, H., Darabpour, E., \& Motamedi, H. (2010). A survey on Hibiscus rosa sinensis L., Alcea rosea L. and Malva neglecta Wallr. as antibacterial agents. Asian Pacific Joumal of Tropical Medicine, 3(5), 351-355.

Shunying, Z., Yang, Y., Huaidong, Y., Yue, Y., \& Guolin, Z. (2005). Chemical composition and antimicrobial activity of the essential oils of Chrysanthemum indicum. Joumal of Ethnopharmacology, 96, 151-158.
Silva, J. A. A., Vizotto, V. J., Giorgi, E., Macedo, S. G., \& Marques, L. F. (1994). Plantas medicinais, caracterização e cultivo. Epagri. Boletim Tecnico. Empresa de Pesquisa Agropecuaria e Difusao de Tecnologia de Santa Catarina S.A., Florianopolis (Brazil), 68, 1-71.

Smith-Palmer, A. (1998). Antimicrobial properties of plant essentialoils and essences against five important food-borne pathogens. Letters in Applied Microbiology, 26(2), 118-122.

Tassou, C. C., Koutsoumanis, K., \& Nychas, G. J. E. (2000). Inhibition of Salmonella enteridis and Staphyloccus aureus on nutrient broth by mint essential oil. Food Research International, 48, 273-280.

Tesche, S., Metternich, F., Sonnemann, U., Engelke, J.-C., \& Dethlefsen, U. (2008). The value of herbal medicines in the treatment of acute non-purulent rhinosinusitis. European Archives of Oto-Rhino-Laryngology, 265(11), 1355-1359.

Tohidi, B., Rahimmalek, M., \& Trindade, H. (2019). Review on essential oil, extracts composition, molecular and phytochemical properties of Thymus species in Iran. Industrial Crops and Products, 134, 89-99.

Traore, N., Sidibe, L., Bouare, S., Harama, D., Somboro, A., Fofana, B., Diallo, D., Figueredo, G., \& Chalchat, J. C. (2013). Activités antimicrobiennes des huiles essentielles de Eucalyptus citriodora Hook et Eucalyptus houseana W. Fitzg. ex Maiden. International Joumal of Biological and Chemical Sciences, 7(2), 800-804.

Trivedi, N. A., \& Hotchandani, S. C. (2004). A study of the antimicrobial activity of oil of Eucalyptus. Indian Journal of Pharmacology, 36, 93-94.

Trombetta, D., Castelli, F., Sarpietro, M. G., Venuti, V., Cristani, M., Daniele, C., Saija, A., Mazzanti, G., \& Bisignano G. (2005). Mechanisms of antibacterial action of three monoterpenes. Antimicrobiol Agents and Chemotherapy, 49(6), 2474-2478.

Yang, X.-W., Li, S.-M., Shen, Y.-H., \& Zhang, W.-D. (2008). Phytochemical and biological studies of Abies species. Chemistry and Biodiversity, 5(1), 56-81.

Younessi-Hamzekhanlu, M., Sanjari, S., Dejahang, A., Karkaj, E. S., Nojadeh, M. S., Gönenç, T. M., \& Ozturk, M. (2020). Evaluation of essential oil from different Artemisia fragrans Willd. Populations: Chemical composition, antioxidant, and antibacterial activity. Journal of Essential Oil Bearing Plants, 23(6), 1218-1236.

Yu, J. Q., Lei, J. C., Yu, H., Cai, X., \& Zou, G. L. (2004). Chemical composition and antimicrobial activity of the essential oil of Scutellaria barbata. Phytochemistry, 65(7), 881-884.

Zazharskyi, V. V., Davydenko, P. O., Kulishenko, O. M., Borovik, I. V., \& Brygadyrenko, V. V. (2019). Antimicrobial activity of 50 plant extracts. Biosystems Diversity, 27(2), 163-169.

Zazharskyi, V. V., Davydenko, P. O., Kulishenko, O. M., Borovik, I. V., \& Brygadyrenko, V. V. (2020). Antibacterial and fungicidal activities of ethanol extracts from Cotinus coggygria, Rhus typhina, R. trilobata, Toxicodendron orientale, Hedera helix, Aralia elata, Leptopus chinensis and Mahonia aquifolium. Regulatory Mechanisms in Biosystems, 11(2), 305-309.

Zazharskyi, V., Davydenko, P., Kulishenko, O., Borovik, I., Brygadyrenko, V., \& Zazharska, N. (2019). Antibacterial activity of herbal infusions against Staphylococcus aureus, Staphylococcus epidermidis and Pseudomonas aeruginosa in vitro. Magyar Állatorvosok Lapja, 141, 693-704. 